\title{
The Analysis of Maqashid Syariah on the Use of Fiat Money and Dinar Dirham
}

\author{
Fatimah Zahara \\ Lecturer at State Islamic University of North Sumatera Indonesia \\ fzahara.uinsu@gmail.com
}

\begin{abstract}
Money as a medium of exchange, has at least two forms, namely fiat money and dinar dirham. This paper discusses the use of fiat money and the use of gold and silver as a currency with its advantages and disadvantages. Furthermore, this article also compares the use of fiat money and dinar dirhams as currency. This paper answers the question of whether gold and silver are the only metals accepted as the currency in the economic system, while other currencies are not. The results of this study indicate that, although the hadith is more likely to state that gold and silver as money, it is not limited to gold and silver. By law, 'Illah of thamaniyyah' which is not restricted to gold and silver but money in general, is supported by Ibn Taymiyah's opinion. In addition to that, the principle of ibahah where in muamalah everything is allowed, as long as it is not prohibited by the texts (Al-Quran and Sunnah). Maqashid AlShariah allows other forms other than gold and silver to be used as currency, if the conditions are demanding so. Metals other than gold and silver are accepted, as long as it can facilitate sharia activities such as paying zakat and rejecting usury.
\end{abstract}

Keywords

fiat money, dinar dirham, maqashid syariah

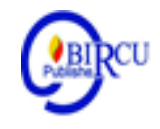

\section{Introduction}

One thing that distinguishes Islamic economics and conventional economics is the view of money function. Money, in conventional economics, not only serves as a means of exchange of goods but also as a means of temporary wealth storage. Contrary to that, Islam views money as a medium of exchange, not a store of wealth. As a means of exchange in the economy, the use of money must be in accordance with the goals of Islamic economics itself (maqashid shariah). Therefore, the type or form of money should be tailored to the purpose or the function itself.

The form of a medium of exchange has a long history, one of which is gold and silver, although lately, the use of both tools is losing the prestige. Several decades later, especially since the monetary crisis of 1997, the use of gold and silver exchange instruments rises back, mainly by Islamic economic scholars. The emergence of discourse (or the movement) back to gold and silver as currency, is not only based on the theological (faith) reason but also based on the reasons of the instability of for fiat money which is even assumed as one of the root causes of the economic crisis.

The emergence of discourse and the use of gold and silver money, not necessarily agreed by Islamic scholars or specifically, scholars who focus in the field of Islamic economics. The debate over the use of gold and silver as currency has existed since the days of the earlier scholars. Some scholars argue that only gold and silver may be the currency in the economic system. Therefore, other currencies are no longer needed. Meanwhile, 
according to some other opinions, although gold and silver coins are applied, other currencies should not be abolished. This paper discusses the use of gold and silver as a currency with its advantages and disadvantages, the use of fiat money as a currency, and the two forms of currency. After comparing the two, this paper provides an analysis of whether only gold and silver, and not any other currency, can be used as a currency in the economic system.

\section{Scholar's View of Dinar Dirham as Currency}

Money in Arabic is called النقود which means good or cash. Lafaz النقود is not found in the Qur'an or Hadith. This is because the Arabs use the word dinar for gold coins and dirhams for silver coins. They also use the word wariq to denote silver dirham and 'ain for gold dinars. While the word fulus is used to indicate an additional means of exchange for buying cheap goods. The fiqh scholars call the currency using the words dinar, dirham and fulus. To show the dinar and dirham, they use the word naqdain (mustanna). According to al-Sarkhasy, nuqud can only be used for transactions on the contained value. Therefore, nuqud can not be appreciated by the object.

Al-Maqrizi said that the issue of money that has been discussed since the year $64 \mathrm{H}$ led to differences of opinion among the classical scholars with all the economic dynamics that occurred at that time. Ibn Taymiyah, for example, agrees to use fulus as a currency, although fulus has not been widely used at the time. Likewise, Ibn Qayyim Al-Jawziyah agrees with his teacher (Ibn Taymiyah) who says that money or a medium of exchange does not have to be in one form, although it must be admitted that inflation at that time was resolved by replacing the currency with other better currencies in quality. ${ }^{1}$

In contrast, Al-Maqrizi states that the medium of exchange is in only two forms, gold and silver because according to him, only these two forms of the medium of exchange are stable from the side of price and wage laborers. Al-Maqrizi took a lesson from the monetary crisis that occurred in the year $806 \mathrm{H}$ where the fulus of the current currency was unable to face the crisis. Some opinions of scholars who agree with Al-Maqrizi are Suyuti (W. $911 \mathrm{H}$ ), Al-Tumurtashi (W. $1004 \mathrm{H}$ ) and Ibn 'Abidin (W. 1252 H). ${ }^{2}$

Some opinions also state that money should be limited in the form of gold and silver based on legal usury. Money is closely related to usury. To prevent the usury, money should be limited in gold and silver.

The evidence supporting this view is:

First, Sunnah Taqririyyah which states that Prophet Muhammad used gold and silver as the currency at that time. This is the evidence that the currency of gold and silver is based on sharia law. Secondly, Mu'amalah and 'Amaliyyah practices such as zakat use gold and silver as a measurement. Likewise, the diyat size and the limit of stolen property is measured by gold and silver. Thirdly, the Quranic verses indicate that gold and silver are the measurements, such as the letter at-taubah verse: 34 which forbids the hoarding of gold and silver which indicate that gold and silver as money. Similarly, Al-Imran: 75, 91 Yusuf: 20, al-

\footnotetext{
${ }^{1}$ Muhammad Aslem Haneef dan Eman Rafiq Barakat, Must Be Limited to Only Gold and Silver? A Survey of Fiqhi Opinions and Some Implication, JKAU, Islamic Econ. Vol. 19. Nomber 1. p. 22

${ }^{2}$ Ibid, p. 24
} 
Kahf: 20.Fourthly, Ijma 'al-Sahabah like (al-khulafa' al-rashidin) uses gold and silver.Fifth, gold and silver are naturally more justifiable.Sixth, the traditions narrated by Ibn Majah prohibit the destruction of the Muslim world's financial system.Seventh, that Shafi'i and Maliki scholars restrict the use of non-gold and non-silver materials as a form of currency.Eighth, the facts show that gold and silver are forbidden to be made as certain ornaments. This shows that gold and silver are indeed reserved for money. Ninth, the use of gold and silver aims to create justice in the financial system. ${ }^{3}$

While the group that does not restrict the form of money only on gold and silver is based on the argument that illat riba is not only limited to gold and silver, but also on other types of money such as cash and paper money. The Hanafis such as al-Shaybani, the Maliki School like al-Hattab and al-Wansharisi, Hanbali Schools like Ibn Taymiyya and Ibn Qayyim, the Zahiri School like Ibn Hazm; Tabi'un like Laith ibn Sa'ad and Al-Zuhri and contemporary scholars such as Yusuf al-Qaradawi, Muhammad Taqi Usmani, and 'Abd Allah Sulayman al Mani' are part of this side of opinion.The reason for the opinion that allows the use of money in the form of fulus or paper money is that although the hadith is more likely to state that gold and silver as money, but the interpretation is not only limited to gold and silver.

This can be seen from the story of Umar bin Khattab who wanted to use something from the camel as a medium of exchange, but not approved by other companions. This shows that the Caliph Umar wanted to do that. Secondly, the principle which states that, in the case of muamalah, everything is permissible as long as it is not prohibited by the texts (Al-Quran and Sunnah) because there is no prohibition against the use of other forms of currency. Third, it deals with the money that brings al-masalih al-mursalah and the authority that allows other currencies regarded as the source of sharia. For example, the first Caliph who made the standard Islamic money was Abdul-Malik ibn Marwan in $76 \mathrm{H}(\mathrm{W} .86 \mathrm{H})$. Prior to this, although gold and silver were used as currencies, other currencies may be used. This shows that the form of currency other than gold and silver can be used as currency, as long as it is not prohibited by the government. Fourth, the habits that people make as a measurement. Fifth, the purpose of the law (maqashid al-Shariah) which allows currency other than gold and silver as a currency, if the conditions demand so. Sixth, the receipt of currencies other than gold and silver as long as it can facilitate the activities of sharia such as paying zakat and usury rejection. Seventh, 'Illah of thamaniyyah which does not restrict money to gold and silver, but money in general which is later supported by Ibn Taymiyah's opinion.

- The Prophet's Hadith narrated by Muslim, Abu Daud, Tirmidhi, Nasa'I, and Ibn Majah, with Muslim texts from 'Ubadah bin Shamit where the Prophet said: ${ }^{4}$

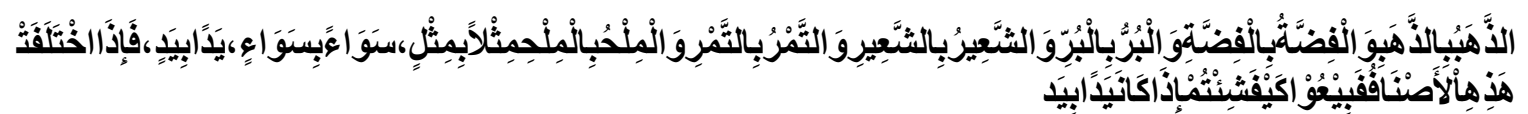

Means:

"(Sale and purchase) is gold with gold, silver with silver, wheat with wheat, sya'ir with sya'ir, dates with dates, and salt with salt (with the necessity) equal and similar and in cash. If the species are different, sell as you wish if it is done in cash.

\footnotetext{
${ }^{3}$ Ibid

${ }^{4}$ Hadis, “ Riwayat Muslim ”, kitab jual beli , edisi 2, (tt, 1987), p. 340
} 
- The Hadith of the Prophet's Muslim history, Tirmidhi, Nasa'I, Abu Daud, Ibn Majah, and Ahmad, from Umar ibn Khattab where the Prophet said: ${ }^{5}$

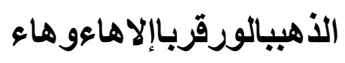

Means:

"(The sale) of gold with silver is usury 'unless it is made in cash"

- Muslim Prophet's Hadith from Abu Sa'id al-Khurdi, the Prophet said:

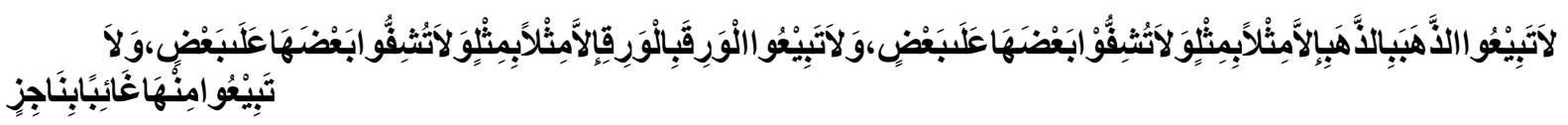

Means: ${ }^{6}$

"Do not sell gold with gold except the same in value, and do not add some of it to others, do not sell silver with silver except the same (in value) and do not add some of it to others, and do not sell gold and silver that are not in cash with cash. "

- The Hadith of the Prophet from the Muslim narrations of Bara 'bin' Azib and Zaid ibn Arqam: ${ }^{7}$

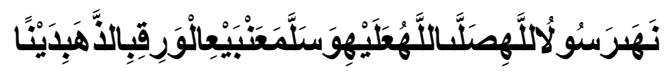

Means:

"Rasulullah Saw forbade selling gold with silver on an account (noncash)."

In the method of understanding the hadith by Yusuf Qardawi, the change of customs which became the nash as the transformation of the golden illat previously tsaman into sil'ah is a condition where gold is no longer an official paying instrument. Nashes associated with the tradition that emerged during the time of the Prophet SAW is temporary. Contemporary scholars allow the removal of literal or textual meaning. ${ }^{8}$

Some scholars point out that the intent of the above hadith is not a currency restriction on gold and silver alone nor does it say that the use of currency other than dinars (gold) and dirham (silver) contains usury. The above Hadith only describes gold dealings with gold or silver with silver which should not be added in price and must be made in cash. In other words, although Rasululllah Saw mentioned dinars and dirhams as currency, this does not mean that the currency to be used is limited to both types.

In Islam is a process of intellectual activity that is comprehensive in order to find, obtain, and at the same time understand the terms contained in the revelation teachings which then transforms the teachings of the revelation into a system that can be implemented in the form of rights and obligations "(Jurisprudence in Islam). The term of the divine will and transforms them into a system of legally enforceable rights and duties). (Kamal, 2019)

\footnotetext{
${ }^{5}$ Ibid

${ }^{6}$ Ibid

${ }^{7}$ Ibid

${ }^{8}$ Yusuf Qardawi, Studi Kritis Sunnah, (Bandung: Trigenda karya, 1995), p. 132.
} 


\section{Review of Literature}

Comparison of Fiat Money with Dinar-Dirham. In practice, the use of fiat money and dinar dirhams has several advantages and disadvantages, such as the following:

\subsection{Fiat Money}

Fiat money is a currency exchange instrument that has been legalized by the government as a legitimate means of exchange in order to facilitate economic activities that take place in a country so that the process of economic activity run quickly and measurably. The practical era of advancement forces the world community to use a very practical means of exchange with consequences that can harm human beings themselves. There are several advantages and disadvantages of fiat money.

\section{a. The advantage of the use of Fiat Money}

- Easy and practical in transactions

The use of banknotes that are easy to carry, store, and exchange makes this type of currency exchange tool widely used in daily economic activities. The level of security in carrying it is also relatively high compared to bringing precious metals as a medium of exchange.

- Low manufacturing cost

The process of making a paper-based exchange tool has a low cost of production so it can save printing costs. With the ability to print dollars, the US government can buy whatever they want from around the world. ${ }^{9}$

- Adding and deducting can be done faster and easier

Because the printing process is cheap and easy, the addition and reduction can be done quickly.

- Can be broken down into any amount

Banknotes can be made in any manner according to the needs of a country.

- Paper money is a source of income for the state

Paper money has become a huge source of state income because it only has a small print cost that the state gets much profit from every printing money they spend.

\section{b. The weaknesses of Fiat Money Usage}

- Easily damaged physically

The form of paper looks good but also easily faded, torn, and also burned because it is made of paper so that the resistance of paper money is low.

- Paper currency can cause high inflation Paper money, viewed extrinsically, can affect the economy and condition of a country because it can trigger inflation. This is because, basically, it is the government policy that makes paper money worth.

- Legitimacy of paper money is very fragile

9 Follow-through Robert Mundell, Currency Areas, Exchange Rate Systems and International Monetary Reform, 2007 
The banknotes are only supported by laws passed by the state, so the condition of the country is very influential on the value of the currency. Paper money in a country can be of no value if the condition of the country gets worse.

- Vulnerable to counterfeiting money

The printing process and materials that are easy to come by make a handful of irresponsible parties forge paper money.

\subsection{Dinar and Dirham}

Precious metals are goods that have a stable selling point and can be used as a stable exchange tool. Dinar is a medium of exchange made of gold so that its value will not decrease with the times. However, this does not mean there are no obstacles in the use of dinars as a medium of exchange. Here are some of the advantages and disadvantages of dinars:

\section{a. Excess Dinar Dirham}

- Dinar is a valuable item

Intrinsically, dinars and dirhams are precious metals that have value without any provisions and laws.

- The dinar exchange rate is more stable and resistant to inflation

The value of the dinar is not influenced by the existing policy or law but in accordance with the value that exists within the dinar itself so that the dinar is always stable in value.

It can last longer because it is made of precious metal. Gold is the best means of the store of value. Compared with other commodities such as paper which although can be used as medium of exchange, cannot save the wealth in a long time. ${ }^{10}$

There are several criteria or measurements that can be used to determine the stability of certain types of money, borrowing Mishkin's criteria cited by M. Lutfi (2007) in his book "Gold Dinar". This paper only looks at two aspects, namely internal stability and external stability.

A currency is considered stable and strong if the currency has sufficient stability. The rate of inflation is very often associated with the existence of money with goods and services available. From here, we can see the rate of inflation of a currency. Inflation occurs when the amount of money in circulation is much more than the goods and services available, resulting in the value of money or purchasing power to go down. In turn, this can lead to an increase in the prices of goods and services.

Several studies have shown that paper currency is prone to inflation. This is due to the amount of money circulating in the market. This usually happens because the banknotes are easy to print.

The currency of the dinar and dirham, on the other hand, is more stable. The stability of the dinar dirham currency has been tested since pre-Islamic times until today. The rate of dinar dirham inflation after 1400 years is zero. For example, the price of chicken at the time of the Prophet Saw. is, let's say, 1 dirham. Now, it would also be around 1 dirham. The recognition of the stability of gold as a means of exchange (money) is a strong factor that can keep the economy well. Greenspan Governor of the Fed (US Central Bank) also recognizes the role of gold in stabilizing the economy.

${ }^{10}$ Jack Weatherford, Sejarah Uang, Bentang Pustaka. 2005, p. 16 
Inflation is very easy and susceptible to fiat money. As a simple illustration, if someone borrows money as much as Rp. 1,000,000, - and he promised to return it with the same amount of ten years to come. Thus, it is very likely that the person has a difficulty to lend the money because the money of Rp. 1000,000, - in the next ten years will be greatly reduced in value.

Gold is the most appropriate choice to suppress inflation in a country because a government is unlikely to print gold coins or banknotes that are not supported by an unlimited gold availability. Therefore, a country must make every effort to increase productivity in order to meet the needs of the state expenditure.

While externally, the value of a country's currency is compared with the value of foreign currency. In this case, the appreciation and depreciation of a currency may depend on the business cycle and economic conditions of a country. The currency will depreciate when the value of the currency falls when compared to other foreign currencies.

In this case, the results of M. Luthfi Hamidi's "Gold Dinar" study of the proven gold appreciation rate in the history of the currency indicate that in 1800 for example, the price of gold per one troy sons was equivalent to 19.39 US dollars, while in 2004, a troy ounce worths 455.757. This shows that after two centuries (200 years), gold experienced a remarkable appreciation of 2,250 percent against the dollar.

In the latest data (end of 2008), the gold dinar exchange rate has exceeded Rp. 1.35 million per coin and was the highest price in 2008. Thus, the gold dinar appreciated by 22.7 percent. Even since the dinar was first printed and circulated in Indonesia in late 2000, the total value of dinar appreciation in the period of eight years is 237.5 percent. ${ }^{11}$

\section{b. The weakness of Dinar Dirham}

The cost of printing dinar is relatively high. In Indonesia dinar is still a valuable item that is considered as a jewelry by the public so that the holder will usually be subjected to VAT tax of $2 \%$ b. It is also difficult to carry on the journey because of its hard shape and size.

\begin{tabular}{|l|l|l|l|}
\hline & Dinar & Fiat & \multicolumn{1}{|c|}{ Information } \\
\hline Value seen & Intrinsic & Extrinsic & $\begin{array}{l}\text { The intrinsic value of } \\
\text { money seen from the content } \\
\text { contained in the item, its weight } \\
\text { and its substance. }\end{array}$ \\
\hline $\begin{array}{l}\text { Physical } \\
\text { endurance }\end{array}$ & Perennially & Not durable & $\begin{array}{l}\text { Money in the form of a } \\
\text { dinar is more durable because it } \\
\text { is not easily torn, faded, burned } \\
\text { and damaged. }\end{array}$ \\
\hline Price of goods & Stable & Inflated & $\begin{array}{l}\text { Since the time of Umar } \\
\text { Bin Khattab, the price of a } \\
\text { chicken remains 1 dirham and a } \\
\text { goat remains 1 dinar }\end{array}$ \\
\hline
\end{tabular}

${ }^{11}$ Republika/16/1 2010 


\begin{tabular}{|l|l|l|l|}
\hline Purchasing power & Stable & Decreased & $\begin{array}{l}\text { Money 100.000 Rupiah } \\
\text { in } 2010 \text { can buy some items of } \\
\text { household needs in contrast to } \\
\text { the money 100.000 rupiah in } \\
2017 \text { which can only buy fewer } \\
\text { items we need In nominal } \\
\text { terms, Rp 100,000 remains, but } \\
\text { the exchange rate decreases. }\end{array}$ \\
\hline Material supply & Limited & Unlimited & $\begin{array}{l}\text { The amount of gold } \\
\text { reserves of the earth is limited, } \\
\text { while paper is unlimited because } \\
\text { it can be renewed }\end{array}$ \\
\hline Material cost & High & Low & $\begin{array}{l}\text { The cost of printing dinar } \\
\text { money is higher than the cost of } \\
\text { printing banknotes }\end{array}$ \\
\hline Falsification rate & Low & High & $\begin{array}{l}\text { Paper money is highly } \\
\text { vulnerable to counterfeiting due } \\
\text { to its cheap material and } \\
\text { production costs. }\end{array}$ \\
\hline
\end{tabular}

The implementation of fiat money in Indonesia from the viewpoint of Islamic economy

The central bank has a very important role in the life of society in general and in economic development in particular. The central bank is the only institution authorized to issue and also circulate currency as a legitimate means of exchange in a country, while maintaining the stability of the medium of exchange. In Indonesia, the medium of exchange in the daily life of the community is fiat money that has been in use for many years. All economic activities use money, whether in the form of metal, paper, deposit, credit card and others. The result is that the circulation of money continues to grow and affects economic activities such as exports-imports, investment, consumption, exchange rate, inflation and economic growth.

The government has authorized the central bank to issue and circulate banknotes on a trust basis without having to be backed up with gold reserves as collateral in the issuance of such notes, as happened in the gold standard era. Therefore, the obligation to maintain the stability of the currency value becomes central bank liabilities to the state and society. The stability of currency exchange rates is essential to support sustainable economic development that ensures the well-being of the people. A stable currency exchange rate can win the public and world's excitement in the conduct of economic activity.

Banknotes issued by a central bank serve as an effective and accountable means of exchange and storage tool in measurement so that it is easier to use to measure a person's wealth. Before reaching its present form, banknotes go through several different phases in a system such as the following: ${ }^{12}$

12 J.P. Croward, al-Mujaz fi Iqtishadiyat al-Nuqud, op. cit. p. 12-14 
- Phase One

If the volume of foreign trade is wider, the profits will increase, and the property grows. Traffickers will entrust their (golden) coins to goldsmiths, gold converters, or religious leaders to prevent theft and robbery. The parties will then provide a deed (title book) that explains the number of coins deposited. This deed itself is not money because it is not widely accepted and is not possible to be used to pay the transaction, but gives the following points to the owner: First, it keeps money from the risk of theft and loss. Second, it allows traders to transfer money from one place to another. These deeds are well received because they are published by a person or an institution with a good financial reputation in the country that comes with a signature and a statement that the penitent will pay the debt as a legal liability to the lender (creditor).

- Phase Two

In this phase, the deed form changes. In the first phase, the deed is written on a certain name and a certain amount. While in this phase, someone who entrusts the coins then receives the deed with the amount of deposit and written on the deed of the payment guarantee against the holder of this deed.

- Phase Three

People's belief in papers published by these financial institutions is growing because they can use them to carry out direct deal contracts without having to exchange them for coins. The first two phases serve as substitutes for coins in total because the papers are merely evidence to establish the number of precious coins. Parties or financial institutions do not issue papers that exceed the number of coins. But in this phase, the papers become the money that people use directly to buy goods or services.

When people perceive the fraud committed by financial institutions where their goal is to gain multiplied profits without assets, people immediately turn to coins. However, the process of redirection is not easy. Sometimes, states are forced to intervene to create stability, self-control the publishing process, require financial institutions to have assets other than papers published, and compensate for the issuance of papers without a limited number of scores. Then, the world's banks handle the publishing process.

- Phase Four

The events of World War I in 1914 were a painful war that made the circulation of the gold balance worsen, as well as increase the state spending. All it encourages countries to hold the balance of gold when previously, it had the strength of the exchange rate derived from the balance of gold worth.

The circulation of money continues to expand and increases so rapidly that it takes over the role of gold and dirhams in economic development, in reality, the value contained in the banknotes is worth according to the price in circulation so that the portion of zakat must also be issued and determined by nisab of the zakat. Thus, the state of banknotes being a measure of people's wealth has been cleared of the rights of the poor. In the calculation of zakat banknotes, we must know that the calculation nisab for gold and silver zakat because the currency in circulation now in form and the system is not described in revelation such as dinar and dirham. Prophet Muhammad SAW said:

Whosoever is given by Allah's treasure, then he does not pay his zakat, Allah will make for him a serpent aqra, which will be worn on his neck the Day of Judgment later, then the snake said: 'I am your treasure trove'

The above hadith mentions the phrase "treasure" and the phrase treasure refers to something that is general, there is no provision in the form of property. This Hadith indicates our obligation to pay zakat and threats to us who do not pay zakat from any property we 
have, except the property that has been determined in the religion of Islam for not being paid zakah.

If the position of banknotes (Fiat Money) has replaced the position of dinar and dirham in a function and system so as to provide value that has a price, the paper money zakat can be converted with zakat of gold and silver. About the obligatory obligation of paper money as a substitute for gold and silver has been firmly confirmed by al-majmu 'al-fiqhiyah (legal drafting institute).

The excerpt of Majlis's decision al-Majma 'al-Fiqihi al-Islami at a trial held in Makkah al-Mukarramah in $1402 \mathrm{H}$. strengthened Majma' al-Fiqihi al-Islami's decision in Oman in Decision no. (9) D. 3/7/86 on the laws of paper currency and changes in currency values.

In fact, the trial of Majma 'al-Fiqihi al-Islami, which was held at the third seminar, in Oman, the capital of the kingdom of Jordan of al-Hashimiah, from 8 to 13 Safar $1407 \mathrm{H} / 11$ s / d $161986 \mathrm{M}$ decided that the currency paper is a legitimate monetary, which contains the properties of the value of the whole price. Therefore, the whole law of gold and silver, such as the prohibition of usury, the obligations of zakat and the other applies to paper currency. ${ }^{13}$

The fuqoha have set the zakat requirement on gold and silver. The terms of the gold and silver zakat is what applies to the banknotes in the determination of the obligatory zakat requirements. Among them are:

- The nisab is enough

- Even a year in the (one-year) year of ownership in the property.

- Debt-free

- Beyond the basic needs

\section{c. Fiat Money, Dinar Dirham in Maqashid Syari'ah review}

Maqashid is a plural form (jama ') of maqshud. While the word is derived from the verbal word qashada which means towards; aim; willing and deliberate. ${ }^{14}$ The word maqshud-maqashid in the science of Nahwu is called maf'ul bih which is something that becomes object. Therefore, the word can be interpreted with 'a purpose' or 'some objectives'. Asy-Shari'ah,on the other hand, is the subject of syara'a which means' the way to the source of water as the source of life. ${ }^{15}$ Therefore, terminologically, al-Maqashid asy-Shari'ah can be interpreted as' the aims of Islamic teachings' or can also be understood as' the purposes of God in outlining the teachings / shari'ah of Islam.

Basic human needs are divided into five, namely:

- The maintenance of religion (ad-din)

- The maintenance of the soul (an-nafs)

- The maintenance of the reasoning skills (al-aql)

- The maintenace of the wealth (al-maal)

- The maintenance of offspring (an-nashl)

Thus, the indicator of the attainment of al-maqasid shari'ah is the fifth of the basic human needs mentioned above. In connection with the use of fiat money currency or dinar dirham based on maqashid syariah, this is seen based on the advantages and disadvantages of each currency. The table above shows that, both fiad money and dinar dirhams used as

\footnotetext{
${ }^{13}$ Wahbab al-Zuhaili, al-Fihqu al-Islami wa adillatuhu, op. cit., juz. 9, p. 4 dan 5.

${ }^{14}$ Hans Wehr, A Dictionary of Modern Written Arabic (London: McDonald \& Evan Ltd., 1980), p. 767

${ }^{15}$ Ibn Mansur al-Afriqi, Lisan al- 'Arab (Beirut: Dar ash-Shadr, t.th), VIII. p. 175.
} 
currency have weaknesses and advantages. Both types of currency when functioning best will not create any conflict with maqashid shariah.

The results of the comparative analysis of Shariah Banking Performance in Indonesia and Malaysia Judging from the Maqashid Shariah Index written by Riky Ramadhani and Evi Mutia shows that the performance of sharia banking, although using fiat money, when viewed from maqashid shari'ah still meet the demands of maqashid although not in maximum level. The same thing goes with the relationship between dinar dirham with maqashid shari'ah.

\section{Conclusion}

Thus, the use of fiat money as a medium of exchange can still meet the demand of the maqashid shariah in the economic system if the use of fiat money is limited to a medium of exchange, not a commodity. Therefore, with this, the underlying assets in fiat money within a country can still meet the demands and goals of sharia (maqashid shariah).

\section{References}

Ibn Mansur al-Afriqi, Lisan al-'Arab (Beirut: Dar ash-Shadr, t.th), VIII. h. 175.

Imam Muslim, kitab jual beli , edisi 2, (tt, 1987), h. 340.

Hans Wehr. (1980). A Dictionary of Modern Written Arabic (London: McDonald \& Evan Ltd)

Jack Weatherford. (2005). [Sejarah Uang, Bentang Pustaka.]

J.P. Croward, al-Mujaz fi Iqtishadiyat al-Nuqud, op. cit.

Kamal, M. (2019). Method of Instinbāth Law of Money Waqf Abu Hanifah Immediate Perspective. Budapest International Research and Critics Institute-Journal (BIRCIJournal), p. 304-313

Muhammad Aslem Haneef dan Eman Rafiq Barakat, Must Be Limited to Only Gold and Silver? A Survey of Fiqhi Opinions and Some Implication, JKAU, Islamic Econ. Vol. 19. Nomor 1.

Robert Mundell. (2007).Currency Areas, Exchange Rate Systems and International Monetary Reform.

Wahbab al-Zuhaili, al-Fihqu al-Islami wa adillatuhu, op. cit., juz. 9, hlm 4 dan 5.

Yusuf Qardawi. (1995). Studi Kritis Sunnah, (Bandung: Trigenda karya) 